\title{
TITLE TO GERMAN SHIPS SEIZED BY THE UNITED STATES DURING THE WORLD. WAR.
}

That the Linited States acquired and was empowered to lake title to the former German vessels, seized in. American ports during the late war, can scarcely be gainsaid; but it would appear that, "in the light of the purpose of the Governnient to act within the limitation of the principles of international law," such title as was procured by it must he qualified by equitable considerations under general public law, at least in this country; otherwise, we must conclude that the enabling statutes are tinged with unconstitutionality.

This vital consideration is somewhat obscured in a recent decision of the District Court for the Southern District of New York:" the quite collateral issue being raised, whether title to these ships vested by direct governmental action and legislation in itself constitutional," notwithstanding the averred general usage or law of nations to the contrary, implying the necessity of prize proceedings in maritime seizures "jurc bclli." This objection was briefly disposed of in the holding of the Court: "International law will be enforced in our courts; but not in the face of a coitstitutional act of Congress." The larger issue, of more momentous inquiry and far-reaching consequence, was nof whether a statute pursuant to the war powers of Congress must be preferred above the rule of the law of nations, which is readily admitted so far as the statute concerns American citizens; but whether an act of Congress, in derogation of the law and usage of nations and the treaties of the United States affirming its understandings, is constitufional, if it operates to defeat the legal and/or equitable title of aliens (though former enemies), guaranteed to them by deed of the United States and its express contract aiming at perpetuity' and consistent with international law. Such a statute cannot be constitutional unless,

\footnotetext{
2 KacLeod v. U. S., 229 U. S. 416,434 (I912). 1023.

"Littlejohn v. U. S., "The Gaelic Prince," D. C., S. D., N. Y., Jan 23;

*Act of Congress, Mfay 1. 1917; Exccutive Order, June 30, 1917.
} 
consistently with the law of nations, it be read to imply an obligation on the part of the United States to make restitution or equitably to indemnify the injured individuals or the government representing them.

Something of the foregoing would seem to have been sensed by the Court in the case of Littlcjohn of Co. $\approx$. Unitcd States of America; ${ }^{*}$ or it was apprehended that the question was not concluded either by the plea to the juriscliction or by the libellant's objection to the Government's procedure in taking the ships, for the Court swallows whole the allegation that prize proceedings should have preceded the seizure; and falls back on the recent treaty of peace with Germany, commenting that it "would seem to confirm all departmental orders regarding the transfer of German property," thus indicating that possibly something further than the aforesaid acts of legislative and executive authority was necessary, or so contemplated to be, to confirm the Government's tenure, or title, or both; at least, the anxiety of the Department of State to conclude this treaty is strongly evidential of something further being requisite. The Court's obiter dictum might also have been a hint to Government council not to rely upon the theory of the Supreme Court's decision in The W'stern Maid, which presupposed absolute title in the United States, and which theory has been the stubject of widespread dissent. ${ }^{5}$

One is compelled to think that the fundamental inquiry should at least have been whether, as between the statute supplemented by the subsequent treaty of peace with Germany, and the rule of international law calling for proceedings in prize, "any other construction" remained, to quote Marshall in. The Charming Betsy, ${ }^{6}$ than that which warranted the Court in adjudicating that a statute alleged to be in violation of international law was paramount in obligation to it. While the conclusion became unavoidable that the title of the United States to former

- See note 2, supra.

- 257 U. S. 419 (I921); see 56 A3rerican Laiv Review 770; to CaliForsia Law Review 333; 20 Michigax LaW Review 533; 22 Colvisaia Law REview 589; contra 18 IlliNots LAw REview 570.

2 Cranch (U. S.) 64, 118 (1804): 
German shipping was perfect, complete and indefeasible, the premises remain uncertain as to whether, under the circumstances, prize proceedings or, if not. then some further. equitable obligation in the Lnited States must have ensued due regard for the rule of the law of nations. " Had, lowever, the conflict of the statute, supplemented by the treaty, with the more fundamental modern usage of nations in respect to the inmunity: of private, non-combatant enemy property from confiscation, been put in issue, the constitutionality of the statute must have been qualified, if not inpeached, except it have been construed to imply ultimate restitution of this shipping, or equitable indemnification therefor, or reparation. That this construction must enter into the statute and equally into the treaty appears to be beyond doubt: "as to such matters as were by the Constitution committed to the custody of the Federal Government, there were applicable thereto the lans' of nations, the naritime law, the principles of equity and the common lawv"'s at least (who will deny it?) as a principle of construction and interpretation." The powers of Congress in peace and in war, as well as the treaty authority, respond to the law of nations "as understood in this country." While the obligation of strict performance may be suspended during a national emergency, the ultimate compensating obligation of the law of nations is not. ${ }^{19}$

\footnotetext{
TThe Supreme Court of the C'nited States has held that under the Prussian treaties of 1799 and 1828 " the power of search and detention for improper practices of neutral shipping continued in time of peace even until the clearance had actually been perfected and the vessel had entered upon the voyage"; this without prize proceedings but in the excrcise of an inherent right in the United States under the law of nations, and "their contract with the vessel not one . they held under the treaty by purchase at a stipulated price." While this decision only touched the seizure and detention clauses, limiting them to territorial waters and the high seas after yoyage commenced, it is observable that the treaties gave immunity from special and hostile embargo, but not from general embargo in the sense of ordinary restraint of princes contemplating reparations. "For full discussion, zide 16 IiLixors L. REv., No. 3, "Embargoes and Detentions under the early American Treaties.") (1899).

- Shiras, J., in MLurray y. Chicago \& N. W. Rwy. Co., 92 Fed. 868

- Vide 9 Californis L. Rev. 470.

${ }^{20}$ It is axiomatic that no single nation can change the law of nations adiersely to its general moral, if not everywhere constitutional, obligation, an obligation by inherent limitation under the Federal Constitution;
} 
The major question then turns upon judicial construction in a case of appropriate jurisdiction. It is by a "superintending judicial authority," said Mr. Justice Wilson," that the law of nations and the treaties of the United States will be enforced, and it is in this sense that the judicial power transcends "the ordinary legislative and executive powers of the general government, and the powers which concern treaties." 12

If a case in admiralty may not be said to arise under the Constitution, ${ }^{13}$ neither may a case turning strictly upon the bincling effect of the laws of nature and of nations, international law obligating the United States to the security of the alien's individual right. If, as Marshall declared, ${ }^{1+}$ cases within the cognizance of the courts which arise under the Constitution "are triable by a rule which exists independent of any act of the legislature or union. That rule is the common or unwritten law . . . which pervades all America"; then, a case, arising under the law of the sea and of nations approved by the Constitution and affirmed by treaty of the United States, must be determined wholly by international law. Any evidence that a general right, derived from the Constitution "by the rigor of the law of nations and the common law," is restrained by the modern usage of nations rests in proof, dissented Story in Brou'n '. United States, 15 that "by the general consent of nations the usage asserted has become incorporated into the code of public law:" it: Marshall had held in the same case, that the mitigations of the "rigid rule, which the humane and wise policy

and it is peculiarly the view of the common law that the municipal laws of a country cannot change that which rests in the universal consent of uations, particularly when stipulated for by treaty, "so as to bind the subjects of another nation." [Miller $v$. Ship Resolution, 2 Dallas I, 4 (178I); see also The Scotia, 14 Wall. (U. S.) 170, I87 (1871); The Paquete Habana, 175 U. S. 677,711 (1900); see also the Insular cases, Downes v. Bidwell, etc.]

${ }^{11}$ Chisholm v. Georgia, 2 Dallas (U. S.) 419, 466 (1793).

2 Ibid. p. 425 ; Cooley, Const. Law (3 ed. 1898), p. 123.

${ }^{23}$ Marshall in Ins. Co. v. Canter, I Peters (U. S.) 511,546 (1828).

"Journal, House of Delegates, Virginia, Jan. 22, 1799, p. 90, from certified copy.

${ }^{15} 8$ Cranch (U. S.) 110, 129 (1814).

16 Vide $7 \mathrm{I}$ U. OF PA. L. Rev. 43-44; Brown v. U. S., note 15 supra. 
of nations has introduced" (against confiscations of private property) "into the practice of nations, though they will more or less affect the exercise of this right. cannot impair the right itself." Of this, Prof. John Bassett Moore comments: ${ }^{17}$ "The supposition that usage may render unlawful the exercise of a right, but cannot impair the right itself, is at variance with sound theory." Marshall later abandoned his preconceptions, holding in Unitcd States v. Percheman "18 "that the modern usage of nations, which has become law," constrained the United States and its courts. ${ }^{19}$

This doctrine ultimately adopted by Marshall applies to the immediate inquiry, whether the securities afforded by the early Prussian treaties are of such character as to constrain the Federal Courts, in the course of appropriate judicial proceedings, to read into the construction of war-time acts of Congresis and the treaty of peace their understandings: Article XXIV of the Prussian Treaty of 799 with the United States notably stipulates:

"It is declared that neither the pretense that war dissolves all treaties, nor any other ahateacr, shall be considered as annulling or suspending this and the next preceding article; but, on the contrary that the state of war is precisely that for which they are provided, and during which they are to be as sacredly observed as the most acknozelcdged articles in the laz' of nature and of nations."

Article XXIII touches and concerns the property of "merchants of either country, then residing in the other" and "in general, all others whose occupations are for the common subsistence and benefit of mankind." "The permission of trade" (maritime commerce) "is for the interest of human society," declares Mal-

27 Dillon: Marshall, Life, Character and Judicial Services, Vol. I, p. 526.

21 7 Peters (U. S.) 51 (1833); vide, also, Dillon, note 17 supra.

${ }^{20}$ Thus, he holds the eighth article of the Treaty of St. Ildefonso "must be intended to stipulate expressly for the security to private property, which the laws and usages of nations without express stipulation would have conferred . . no construction, which would impair that security further than its positive words require, would seem to be admissible. titles of individuals . . . so far as they were consummated, might be asserted in the courts of the United States independently of this article . . the construction which we now give the article must enter into the construction of acts of Congress on the subject." 
lo::" Then the domiciliary objection is substantially foreclosed. so far as concerns the privately German-owned merchant marine in American ports at the beginning of the war; and the still larger security as to property within American territory finds support in Marshall's comment, in the famous debate in the case of Jonathan Robins: "A case in law and equity proper for judicial determination may arise under a treaty, where the rights of individuals are to be defended in court, as under the fourth and sixth articles of the treaty of peace with Great Britain, or under those articles of our late treaties with France. Prussia. and other nations. which secure to the subjects of those nations. their property within the Unitcd States."

But whatever doubt may exist on this point, as to the restricted effect of the Prussian treaty's stipulations for the event of war, would appear to be removed when Marshall's opinion in United States 2 . Percheman ${ }^{22}$ is examined in the light of Pollard $:$ : Kibbe, ${ }^{23}$ evidencing that the principle of the security of private property taken by conquest had been consecrated by "the usage of the civilized world," and that Marshall's decision in Foster $\%$. Ncilson, ${ }^{24}$ in part reversed by the Percheman case, afforded no basis for the pretension that it controverted or abrogated that principle, though silent on the question.

Further, it is very important to distinguish between the continuing obligation of treaties affirming new understandings of the law of nations and those which, in respect of legislative modification and repeal, are within the power of Congress.": Hamilton writes: "Treaty stipulations, which are designed to operate in case of war. preserie their force and obligations when war takes place," ${ }^{26}$ and "our treaties and the law of nations form

= De Jure Maritimo et Navali, Vol. 2, Chap. XVI (1;69).

${ }^{21}$ House of Rep. of Congress, March 4, 1800.

Note I8 supra.

${ }^{2}{ }_{14}$ Peters (U. S.) 353, 402 (1840); see also 7 MItwivesota L. Rey. II3. "Treaties Made or Which Shall Be Mfade under the Authority of the United States."

* Peters (U. S.) 243 (1824).

"Vide Mfixisesota L. Rev., note 23 supra.

5 Hamilton's Works (Lodge ed.) 126. 
a part of the law of the land"; "I "an established rule of the law of nations can only be altered by agreements bitween all the civilized powers, or by a new usage. generally adopted and sanctioned by time." -s Marshall declared in The Socicty for the Propagation of the Gospel a. Nea Hawen:" "lle think that treaties stipulating for permanent rights and general arrangements and professing to aim at perpetuity. and to deal with the case of war as of peace, arc at most only suspended while it lasts; and unlcss they are ccaiced by the partics, or new and repugnant stipulations are macle. they revive in their operation at. the return of peace."

"That treaties may amount to a law of nations follows from the definition of that law." 30 If such be their nature, their legislative modification or repeal finds positive limitation, and this whether they be considered as repealing or affirming the general law, making exceptions to it, which are to constitute a particular law, or whether explanatory of the law of nations, "in which case they are first a law between the parties themselves, and next a sanction to the general law, according to the reasonableness of the explanation and the number and character of the parties." 31 .Judicial power and cognizance in the Federal Courts must on the one hand operate to constrain legislative enactment with respect to their modification or repeal, and, on the other, in case of appropriate jurisdiction, serve to determine the constitutionality of the act of government in question. Such treaties clearly transcend the purposes of ordinary domestic legislation and call to their aid the totality of subsisting authorities under the Constitution. They must offer a reasonable and lawful crception to the rule that treaties conferring private rights "of a nature to be enforced in courts of notice and which furnish, in casis otheraise coynizable in such courts, rules of decision, are subject to such act as Congress may pass for their

27 \& Hamilton's Works (Lodge ed.) 1.46 ("Pacificus").

$=5$ Hamilton's Works (I.odge ed.) 218.

8. Wheat. (L. S.) 464.494 (I823).

${ }_{2} 2$ Madison's llorks 250 , published by order of Congress.

$=$ Note 30 supra. 
enforcement, modification or repeal." 32 Treaties stipulating for rights or establishing a usage consistent with the law of modern usage of nations and those principles which lie at the foundation of our jurisprudence, if obligatory on the courts, ${ }^{33}$ cannot be less obligatory on the political branches of the Government, or, to say the least, upon officers of the United States acting under statutes contravening their understandings.

No waiver of permanent rights granted by the early treaties with Prussia can, in fact, be admitted under recent agreements with Germany. The obligation of the early American treaties, assuring, in effect, the restitution as well as the security of private enemy-owned property upon the coming of pence, is not voidable by act even of a foreign sovereign; ${ }^{34}$ nor is such act adequate authority to release the United States from its immediate cluty under the general usage and law of nations as to post bcllum possession. ${ }^{35}$ The juris et scisinae conjunctio of the United States, however valid by authority of war-time powers, or contingently extencled, as is the popular conception, by the treaty of peace with Germany, must consist with the equitable obligation of the United States to fulfill its undertakings under the aforementioned clauses of the early Prussian treaties, not abrogated by the existence of war. All mention of these treaties was scrupulously avoided by the framers of the more recent treaty of peace and executive agreement with Germany. Does a title, acquired by a seizure in time of war, and good, as the Federal District Court has recently held, require that the German Govermment shall render it more valid by formal assent, or ratify, as the Senate ratifies a treaty?

Under the treaty of peace with Germany, ${ }^{36}$ the satisfaction. of all private American claims against Germany, etc., and the Confriming to the United States all "seizures" imposed or made

* Head Money Case, 112 U. S. 580 (I884); Whitney v. Robertson, 124 U. S. 190 ( 1887$)$.

C. J. Marshall in The Peggy, I Cranch (U. S.) 103 (I80r).

"Fletcher v. Peck, 6 Cranch (U. S.) 87 (1810).

${ }^{2}$ Vide 55 American L. Rev. 877.

$\Rightarrow$ Aug. 25, 1921. 
by the United States during the war, are the salient and express conditions upon which turns the retention of German property in the possession or control of the United States. There is the further condition that, by reference to the treaty of Versailles, should these conditions not be fulfilled, and confiscation ensue, Germany will indemnify her citizens pursuant to the understandings of that treaty; but this indemmification in practice has proven so far from equitable as to amount to confiscation. If, as they must, treaties of the United States are to be construed in the light of the law of nations, the peace treaty' with Germany, and, indeed, the tltimate authority to deal with the aforesaid property is found to be constrained by principles of international law affirmed by prior American treaties. Upon principle, "a party to a contract cannot pronounce its own deed invalid, although that party be a sovereign state." 3 i While the early Prussian treaties nay have been abrogated by the war-not so their securities. It will be admitted "that a right once vested does not require for its preservation the continued existence of the power by which it was acquired. If a trcaty or any other law has performed its office by giving a right, the expiration of the treaty or law cannot extinguish the right." $\$ 8$ The rights of Germans, whose property has been taken by the United States; are within the protection of the Constitution and the law of nations as understood in this country, and any treaty of the Lnited States, law or act of executive authority nust contemplate their security: The custodia legis of the United States is subject to the principle "rcintcyranda sunt ommia spoliato antequam procedatur ultcrius."

\section{Joseph IVhitla Stinson.}

\section{Nicw York City.}

Copyright 1923. (All rights rescrved save publication by the UNIvERsity of Pexisyliania Law Review.)

"Fletcher v. Peck, note 34 supra.

$\Rightarrow$ For a more full discussion, sce 55 Aurricax L. Rev. 877, 15 Illinors L. REv. 374,70 L. of PA. L. REv. 185. 